\title{
Medisinsk historie - hvorfor og hvordan?
}

At medisinen har en historie, er det få som vil bestride. Men om den betyr noe særlig for oss og for hvordan man skal bedrive faget, er det mindre lett å bli enig om. Litteraturen om medisinsk historie er omfattende: På den ene side finner vi tunge akademiske bøker, gjerne basert på arkivforskning, på den annen de populærvitenskapelige bidragene om alt fra grøss til heroisme, for eksempel Siddhartha Mukherjees populærhistoriske bok om kreft (1).

Sistnevnte sjanger dominerer fagfeltet. Søker man etter historisk litteratur på PubMed, finner man hovedsakelig korte tekster, skrevet av leger og publisert i medisinske tidsskrifter. Faghistoriske bidrag er sjeldnere. Det skyldes nok i utgangspunktet fagets beskjedne størrelse. I Norge kan man telle på to hender hvor mange som driver med medisinsk historie til daglig. De fleste bøker og artikler om emnet er derfor skrevet av forfattere som ikke selv er faghistorikere. Hva så? kan man kanskje spørre seg, det vitner jo om stor interesse for feltet. Kan det likevel være en utfordring for fagets profesjonalitet? Det er ikke lett å komme trekkende med metodekrav til historieforskningen når man står i fare til å bli utkonkurrert av sitt eget publikum.

Å elske historie er ikke det samme som å kunne utforske og skrive den. Historiografi skrevet av legfolk er gjerne dominert av anekdoter. For å gi et eksempel fra min egen forskning: Det finnes hundrevis av publikasjoner om det som kalles «Kochs postulater», et sett av kriterier for å bestemme infeksiøs kausalitet, skrevet av den tyske legen Robert Koch (1843-1910) i 1880-årene. Men Koch skrev aldri noen postulater. Anekdoten om at han gjorde det, har vist seg å bli forskningens overmann (2). Den helt grunnleggende forskjellen mellom dikt og historie er at dikteren kan dikte fritt, mens historikeren må basere sin fortelling på hva som kan etableres som fakta.

$\AA$ beherske historiefaget i sin alminnelighet innebærer at man bruker metoder som i utgangspunktet har to trinn. Først må man etablere fakta, dernest argumentere for dem (3). For å etablere fakta må man skille tradisjon fra historie, altså skille mellom det vi alle tror er gammelt og det som faktisk er det. Dette krever tid og nøyaktighet. I eksemplet med Kochs postulater må man sjekke originalskrifter, brev og andre dokumenter. Andre trinn - argumentasjonen er å gi en historisk forklaring. Det skjer gjerne i form av en fortelling. Mens mye av den moderne medisinen er basert på abstraherende analyser - om de nå er eksperimenter eller statistikk - er historisk vitenskap basert på fortellinger som bringer inn en saks eller en hendelses kontekst. I prosjektet Global Burden of Disease beskriver man for eksempel sykdommenes samtidshistorie, men bruker da epidemiologiske metoder, som ligger fjernt fra historiefagets. Mens forskerne som er tilknyttet dette prosjektet tilbakedaterer dagens sykdomsbegreper i sine stadig lengre statiske løp, insisterer historikerne på at slike begreper varierer over tid og må forstås i sin historiske kontekst (4). Det er mye å vinne gjennom å kontekstualisere en sak. Ta for eksempel febertermometerets historie. Instrumentet ble tatt i bruk på sykehus på 1800-tallet, først 300 år etter det ble funnet opp. Først da hadde legene begynt å betrakte kroppens fysiologi som noe målbart. Vekt, høyde, temperatur og puls ble underkastet samme tilnærming. Feber, som er mye eldre som begrep, ble til temperatur, kroppens normaltemperatur ble bestemt, og avvik - som feberkurver - ble brått viktige i den medisinske diagnostikken (5).

Interessen for medisinsk historie er stor, men nytten av virksomheten for både samfunnet og medisinen minsker hvis ikke faktagrunnlaget er sikkert og metodikken stringent. Ingen er tjent med lemfeldighet her. Selv om det ikke finnes noen absolutte sannheter i historisk forskning, er den empirisk av natur, og feil eller oppspinn kan identifiseres. Behovet for pålitelig informasjon i samfunnet er gitt, og det er historikernes oppgave å levere den. For å bruke et mer betent eksempel: Historisk informasjon kan brukes som grunnlag for en rasjonell debatt om vaksinenes pro et contra. Her viser historisk forskning faktisk at noen vaksiner har så store beskyttende effekter at dette blir synlig i befolkningsstatistikkens lange løp noe som knapt kan sies om andre medisinske teknologier (6).

Hva kan være en farbar vei for medisinsk historie? Det ville være helt feil å lage en skillelinje mellom medisinen og dens historie. Faget er etterspurt og populært og hører hjemme både i spesialpublikasjoner og i tidsskrifter som retter seg mot helsearbeidernes verden. Utover sin mangfoldige praksis har medisinen et behov for refleksjon. Gjennom å vise oss fortiden og hvordan den preger samtiden klarer medisinsk historie å bidra til dette. Men for å kunne fremme en kunnskapsbasert medisin er det avgjørende at slike bidrag baseres på et tilstrekkelig nivå av historisk metode. Først da sikrer vi at vi ikke lurer vårt publikum med noe som ser ut som historie, men som egentlig er diktning. Dette gjelder uansett om bidragene leveres av profesjonelle eller av folk som elsker saken altså amatører i ordets bokstavelige betydning. Medisinen er faglig og metodisk sett veldig sammensatt. Humanistiske metoder, som medisinsk historie er basert på, er en naturlig del av dette.

\section{Christoph Gradmann}

christoph.gradmann@medisin.uio.no

Christoph Gradmann (f. 1960) er historiker ved Institutt for helse og samfunn, Universitetet i Oslo. Han har særlig forsket om den medisinske mikrobiologiens historie fra 1800-tallet til i dag og har skrevet en biografi om den tyske legen Robert Koch. Han driver for tiden med et samtidshistorisk prosjekt om tuberkuloseresistens i global helse.

Forfatter har fylt ut ICMJE-skjemaet og oppgir ingen interessekonflikter.

\section{Litteratur}

1. Mukherjee S. Keiseren over alle sykdommer: kreftens biografi. Oslo: Press, 2013.

2. Gradmann C. A spirit of scientific rigour: Koch's postulates in twentieth-century medicine. Microbes Infect 2014; 16:885-92.

3. Tosh J. The pursuit of history. Aims, methods and new directions in the study of modern history. Harlow: Pearson, 2010

4. Jones DS, Podolsky SH, Greene JA. The burden of disease and the changing task of medicine. N Engl J Med 2012; 366: 2333-8.

5. Hamlin C. More than hot: a short history of fever. Baltimore, MD: Johns Hopkins University Press, 2014

6. Bourdelais P. Epidemics laid low: a history of what happened in rich countries. Baltimore, MD: Johns Hopkins University Press, 2006. 